\title{
When pneumonia becomes a double congenital diaphragmatic hernia
}

\author{
Andre Goulart, ${ }^{1}$ Helena Torrão, ${ }^{2}$ Pedro Leão ${ }^{1,3}$
}

${ }^{1}$ Department of General Surgery, Hospital de Braga, Braga, Portugal

${ }^{2}$ Department of Radiology, Hospital de Braga, Braga, Portugal

${ }^{3}$ Life and Health Sciences Research Institute (ICVS), Braga, Portugal

\section{Correspondence to}

Dr Andre Goulart, andre.b.goulart@gmail.com

Accepted 14 January 2015

\section{DESCRIPTION}

An 89-year-old woman presented to the emergency department with cough for the past couple of days. Chest X-ray revealed an area of condensation at the inferior lobe of the right lung, suggestive of pneumonia (figure 1). This image was similar to another X-ray that had been taken the year before.

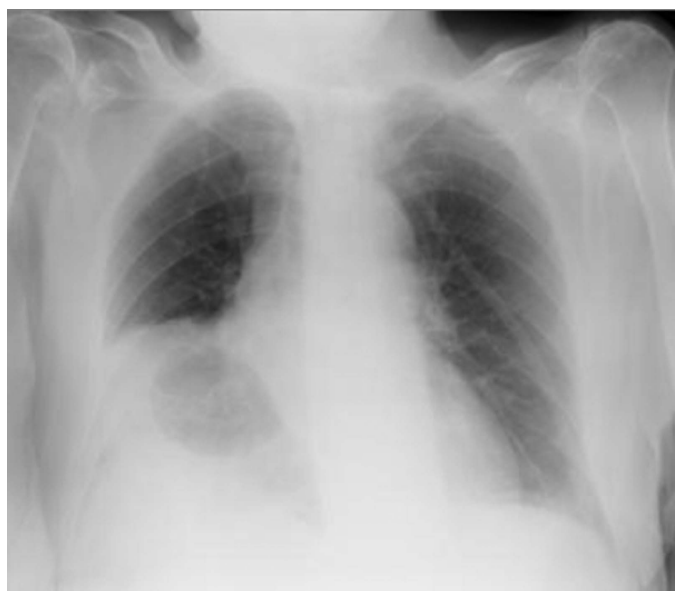

Figure 1 Chest X-ray.
In additional studies, CT scan revealed a large Morgagni hernia with intrathoracic colon on the right and a Bochdalek hernia on the left (figure 2). The patient was discharged with symptomatic medication. Because she improved and had no further symptoms related to the hernias, no surgical treatment was given.

Congenital diaphragmatic hernias are rare anomalies (1/2000 pregnancies) and account for nearly $8 \%$ of major birth defects, of which Bochdalek hernia is the most common (95\%), being primarily diagnosed in early childhood; Morgagni hernia is less frequent $(5 \%)$ and is usually identified in adults. ${ }^{12}$ The diaphragm defect is on the left in $80 \%$ of patients. ${ }^{1}$ Congenital diaphragmatic hernias occur when there is a development defect of the diaphragm's muscular components, which usually leads to impaired pulmonary function and an early diagnosis in life. However, some patients may not develop symptoms until adulthood. ${ }^{2}$

The association of both is extremely uncommon and, to the best of our knowledge, these forms of congenital diaphragmatic hernia that develop on both sides and remain asymptomatic until old age have not been previously reported.
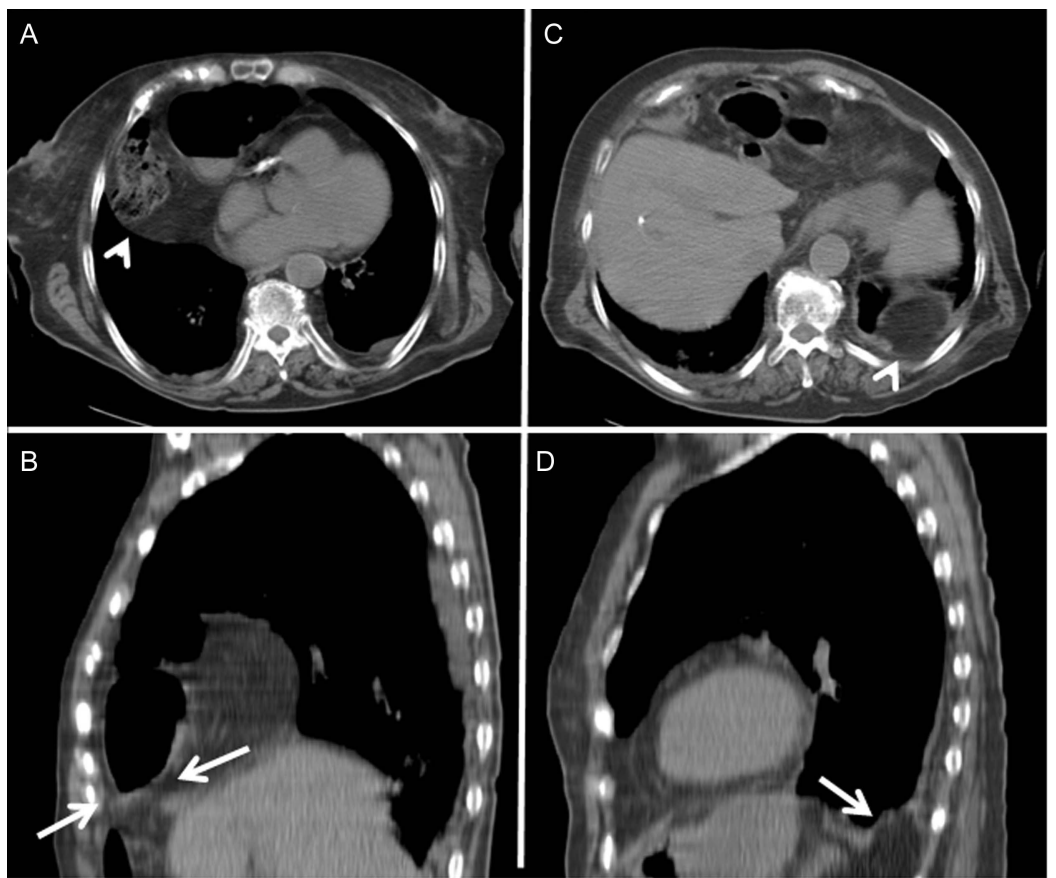

Torrão H, Leão P. BMJ Case Rep Published online: [please include Day Month Year] doi:10.1136/bcr-2014208988
CrossMark
Figure 2 Morgagni hernia: (A) axial CT scan showing an air-containing mass (arrowhead) and (B) sagittal reformatted view showing a diaphragmatic defect (arrows) and the herniated intestine. Bochdalek hernia: (C) CT scan showing a posterior left paraspinal fat-containing lesion (arrowhead) and (D) multiplanar reformatted image clearly depicting the diaphragmatic defect and fat herniation without organ entrapment (arrow). 


\section{Learning points}

- Congenital diaphragmatic hernias are rare and the presence of two different hernias in the same patient is even more uncommon.

- Although they usually manifest earlier in life, congenital hernias should be considered, regardless of age.

Contributors AG was involved in conception and design of the work, drafting the work, interpretation of the data and final approval of the version. HT was responsible for interpretation of the data, revising and final approval of the version. $\mathrm{PL}$ was involved in conception and design of the work, interpretation of the data, revising and final approval of the version.

Competing interests None.

Patient consent Obtained.

Provenance and peer review Not commissioned; externally peer reviewed.

\section{REFERENCES}

1 Jelin EB, Kim TN, Nathan N, et al. Synchronous ipsilateral Bochdalek and Morgagni diaphragmatic hernias: a case report. J Pediatr Surg 2011;46:2383-6.

2 Schumacher L, Gilbert S. Congenital diaphragmatic hernia in the adult. Thorac Surg Clin 2009;19:469-72.

Copyright 2015 BMJ Publishing Group. All rights reserved. For permission to reuse any of this content visit

http://group.bmj.com/group/rights-licensing/permissions.

BMJ Case Report Fellows may re-use this article for personal use and teaching without any further permission.

Become a Fellow of BMJ Case Reports today and you can:

- Submit as many cases as you like

- Enjoy fast sympathetic peer review and rapid publication of accepted articles

- Access all the published articles

- Re-use any of the published material for personal use and teaching without further permission

For information on Institutional Fellowships contact consortiasales@bmjgroup.com

Visit casereports.bmj.com for more articles like this and to become a Fellow 